\title{
XXI. On an accelerating process in photography
}

\section{J. Middleton F.G.S.}

To cite this article: J. Middleton F.G.S. (1850) XXI. On an accelerating process in photography, Philosophical Magazine Series 3, 37:249, 178-179, DOI: 10.1080/14786445008646580

To link to this article: http://dx.doi.org/10.1080/14786445008646580

册 Published online: 30 Apr 2009.

Submit your article to this journal 준

Џ Article views: 2

Q View related articles $₫$ 
cannot be inferred by the rule :-Compute the grains of lime, magnesia, oxides of iron, alumina, in a gallon of water, each into its equivalent of chalk: the sum of these equivalents will be the hardness of the water.

3rd. That the degrees of hardness of a water containing magnesia and lime salts, as shown by the saap-test as it is now applied, cannot in almost every case be taken as representing the amount of these salts in the water; nor in nearly every instance can it be considered as giving the amount of lime in a water when magnesia is present.

4th. That water might show by the soap-test a small degree of hardness in comparison to the considerable quantities of salts of magnesia and of lime it might contain, and trusting to this method of analysis alone when selecting water for ordinary use and for steam purposes, might lead to a water being selected which might not be conducive to the general healih, and which would leave considerable deposit in vessels in which it was boiled, - a great deterioration to its use in steam generating.

\section{On an Accelerating Process in Photography.} By J. Middle'Ton, F.G.S.**

$\mathbf{T}$

HE following method of preparing sensitive paper, may, perhaps, be welcome to photographers on account of the great sensibility which it confers; it has the additional recommendation, moreover, of being very simple and constant in its results.

I beat up albumen of the egg of the duck till it becomes liquid, and then mix it with water in the proportion of eighty grains of the former to an ounce of the latter. I add to this solution iodicle of potassium in the proportion of twenty-five grains to the ounce. Prior to the application of this solution I wash the size from the side to be rendered sensitive, by means of a camel-hair brush, and when dry I float the paper on the solution, for from three to four minutes, and when drained and dried I lay it aside for use.

When about to be used for taking a picture, the paper, prepared as above directed, is to be washed with aceto-nitrate of silver, in the proportion of sixty grains of nitrate and eighty grains of acetic acid to an ounce of water (Talbot's strength). I apply the solution with a glass rod, in the manner recommended some time since by a writer in the Philosophical Magazine, using about forty grains of it to a

* Communicated by the Author. 
quarto page, and allow the paper to dry in the dark; it is now ready for the camera. While applying the sensitive coat, as also while bringing ont the picture, I take the precaution to use a yellow light. I find that from ten to fifteen seconds is, with ordinary sun-light, sufficient exposure, the latter being generally too great.

When the picture has been taken no trace of it appears on the paper, but it comes speedily out on the application of a saturated solution of gallic acid. I turn up the edges of my paper and pour the solution on till the paper is entirely covered, and keep it so till the picture has come sufficiently out, when I fix it in the usual way.

I find that if bromide of potassium be substituted for iodide of potassium, in the first process, a picture is obtained; but the time of exposure required is then about a minute. Again, bromide or chloride of potassịum does not serve to accelerate, as in the ordinary processes, but the contrary; gallic acid too, added to the aceto-nitrate, destroys sensitiveness. I find also, that if the albumen be dried, and alterwards dissolved up and used as above described, it has lost its photographic value; a circumstance, which would seem to indicate that photographic properties are connected with or dependent upon molecular arrangement.

The employment of albumen in photography is not, $I$ believe, new: it has not, however, so far as I am aware, been used in the way or with the effect stated above.

Agra, 18th June, 1850.

XXII. Algerite, a new Mineral Species. By Richard Crossuey, Esq.*

DETAILED description of this mineral by Mr. F.
Alger, accompanied with an analysis by Mr. T. S. Hunt,
was published in the American Journal of Science for July
1849 , vol. viii. I have since, at the request of Mr. Alger,
made a re-examination. The results obtained vary but little
from those of Mr. Hunt, though this variation is essential to
the formula. Algerite, named by Mr. Hunt in honour of ita
discoverer, Mr. Alger, is found in the town of Franklin,
Sussex County, New Jersey. It is sparingly disseminated in
prismatic crystals through a bed of pure crystalline limestone.
The crystals when undecomposed are of a honey-yellow coloun,
and more or less penetrated by the matrix : some are conta-
minated by graphite, and others are encrusted with idocrase,

* Communicated by W. G. Lettsom, Esq. 